\title{
Hubungan Kunjungan Ibu ke Posyandu dengan Jumlah Balita Bawah Garis Merah (BGM) di Desa Tente Kecamatan Woha Kabupaten Bima
}

\author{
Nurlaila Fitriani \\ Stikes Yahya Bima \\ Ani_Nuni@Yahoo.Com \\ NIDN. 0804039201
}

\begin{abstract}
Abstrak: Di bawah garis merah (BGM) balita adalah balita yang beratnya sama atau di bawah merah pada Kartu Menuju Sehat (KMS). Ibu yang aktif mengunjungi posyandu setiap bulannya, maka status perkembangan dan gizi dapat dipantau oleh petugas kesehatan melalui KMS yang dapat mengurangi kejadian kasus balita BGM. Tujuan dari penelitian ini adalah untuk mengetahui hubungan antara keaktifan ibu dalam pelayanan kesehatan terpadu dengan pengurangan jumlah balita di bawah garis merah (BGM) di Desa Tente, Kabupaten Woha, Kabupaten Bima. Penelitian ini merupakan penelitian analitik, data diambil dengan cross sectional, subjek penelitian ini adalah dua ratus delapan belas bayi berusia satu sampai lima puluh sembilan bulan. Data dianalisis dengan uji chi-square. Berdasarkan penelitian yang telah dilakukan menunjukkan bahwa ibu yang secara aktif mengunjungi posyandu namun dengan status gizi BGM pada anak-anak adalah 34,5\% sedangkan ibu tidak aktif mengunjungi posyandu namun status gizi BGM pada anak adalah 94,1\%. Analisis data penelitian menggunakan uji chi-square, menunjukkan bahwa nilai $\mathrm{p}=0,000$ dengan tingkat signifikansi (alpha) sebesar 0,05. Dengan demikian nilai p kurang dari tingkat signifikan ( $\mathrm{p}$ kurang dari alpha), sehingga Ho ditolak yang berarti ada korelasi keaktifan ibu dengan berkurangnya jumlah balita BGM di Desa Tente, Kec. Woha, Kabupaten Bima. Saran dari penelitian ini adalah ibu diharapkan dapat memanfaatkan sebaik-baiknya fasilitas posyandu setiap bulan, karena selain mudah dan murah untuk mendapatkan perawatan kesehatan tanpa biaya untuk anak-anak mereka, ibu juga dapat memantau pertumbuhan dan perkembangan bayi secara teratur setiap bulan melalui buku balita KMS, jadi bila ada masalah tentang perkembangan dan perkembangan bayi bisa segera ditangani dan dibantu oleh petugas kesehatan dengan cepat dan tepat.
\end{abstract}

Kata kunci: Keaktifan ibu, anak BGM, Posyandu

Palapa: Jurnal Studi Keislaman dan Ilmu Pendidikan Volume 6, Nomor 1, Mei 2018; p-ISSN 2338-2325; e-ISSN 2540-9697; 


\title{
Correlation between Mother's Activeness Integrated With Health Service Number Reduction of Toddler Below The Red Line
} (BGM)

\author{
In Tente Village, Woha District, Bima Regency
}

\author{
Nurlaila Fitriani \\ STIKES Yahya Bima \\ ani_nuni@yahoo.com \\ NIDN. 0804039201
}

\begin{abstract}
Below the Red Line (BGM) toddler is a toddler whose weight is equal or below the red on a Card Towards the Healthy (KMS). Mothers who actively visit posyandu each month, then the developmental and nutritional status can be monitored by health workers through KMS that can reduce the incidence of cases of toddlers BGM. The purpose of this study was to determine the correlation between mother's activeness in integrated health service with number reduction of toddler below the red line (BGM) in Tente village, Woha district, Bima regency. This research was a survey analytical, data was retrieved with crosssectional, the subjects of this study were two hundred and eighteen infants aged one to fifty-nine months. Data analyzed using chi-square test. Based on the research that has been done shows that mothers who actively visit posyandu but with BGM nutritional status of children was $34,5 \%$ while the mother is not active visit posyandu but the BGM nutritional status of children was $94,1 \%$ Based on the analysis of the research data using the chi-square test, showed that the $\mathrm{p}$ value $=0,000$ with the significance level (alpha) of 0.05 . Thus the $p$ value is less than significant level ( $p$ less than alpha), so Ho is rejected which means that there is a correlation of mother's activeness with a reduction in the number of BGM toddler in the village Tente, Woha districk, Bima regency. Suggestions of this study are mothers are expected to be able to make the best use posyandu facilities monthly, because in addition to easy and cheap to get no-cost primary health care for their children, mother can also monitor the baby's growth and development regularly each month via KMS toddler book, so when there are problems about the baby's growth and development can be immediately addressed and assisted by health workers quickly and precisely.
\end{abstract}

Key words: Mother activeness, BGM children, Posyandu 


\section{Pendahuluan}

Gizi di bawah garis merah adalah keadaan kurang gizi tingkat berat yang disebabkan oleh rendahnya konsumsi energi dan protein dari makanan sehari-hari dan terjadi dalam waktu yang cukup lama.Tanda-tanda klinis dari gizi buruk secara garis besar dapat dibedakan marasmus, kwashiorkor atau marasmic-kwashiorkor (WHO, 2005).

Konsumsi gizi yang baik merupakan modal utama bagi kesehatan individuyang dapat mempengaruhi status kesehatan seseorang. Seseorang yangmengkonsumsi asupan gizi yang salah atau tidak sesuai dengan kebutuhan tubuh,maka akan menimbulkan masalah kesehatan. Malnutrition (gizi salah) merupakankeadaan mengkonsumsi asupan gizi yang salah,dalam bentuk asupan yang berlebihan ataupun kurang, sehingga dapat menimbulkan ketidakseimbanganantara kebutuhan dengan asupan yang diperlukan oleh tubuh. Masalah kesehatananak yang sering terjadi di Indonesia akibat asupan gizi yang kurang diantaranyaadalah Kekurangan Vitamin A (KVA), Gangguan Akibat Kekurangan Yodium(GAKY), anemia, dan Kekurangan Energi Protein (KEP) (Sulistyoningsih, 2011).

Masalah gizi anak yang terjadi dikarenakan oleh ketidakseimbangan antaraasupan dan keluaran zat gizi (nutritional imbalance) yaitu asupan kebutuhan gizi anakyang melebihi keluarannya atau asupan kebutuhan gizi yang kurang darikeluarannya. Kesalahan pola asuh orang tua dalam memilih makanan yangdiberikan kepada anaknya untuk dikonsumsi dapat memicu terjadinya masalahgizi pada anak. Akibat dari masalah gizi anak dapat berupa penyakit kronis, beratbadan berlebih dan kurang, pica, karies dentis serta alergi makanan tertentu yangsering terjadi pada anak (Arisman, 2009).

Menurut United Nations International Children's Emergency Fund(UNICEF) ada dua penyebab langsung terjadinya masalah kekurangan gizi padaanak, yaitu kurangnya asupan gizi dari makanan yang dikonsumsi dan akibatterjadinya penyakit yang mengakibatkan infeksi. Kasus giziburukdapat diakibatkan oleh beberapa factor yaitu: faktor ketersediaan pangan yang bergizidan terjangkau oleh masyarakat; perilaku dan budaya dalam pengolahan panganserta pola asuh anak; pengelolaan kesehatan yang buruk dan perawatan kesehatanyang tidak memadai (Atmarita, 2004). Sekitar 1,7 juta anak di bawah lima tahun (balita) di Indonesia terancam mengalami gizi buruk yang tersebar di daerah tertinggal seluruh Indonesia. Menurut Badan Koordinasi Keluarga Berencana Nasional (BKKBN) tahun 2007, jumlah balita di Indonesiamencapai $17,2 \%$ dengan laju pertumbuhan penduduk semakin meningkat menjadi 2,7\% pertahun. Menurut UNICEF, Indonesia merupakan negara yang berada di peringkat kelima dunia dengan jumlah balita yang terhambat pertumbuhan dan perkembangannya paling besar sekitar 7,7 juta balita (Departemen Kesehatan RI, 2007). 
Menurut peneliti fakta yang terjadi dalam melakukan wawancara serta melihat langsung dalam kegiatan BGM ini yg peneliti dapatkan iayalah balita yang menderita kalori protein ( KKP) atau kurang gizi penyebapnya ini di karnakan kurangnya pendidikan dan keterampilan serta tidak cukup persediaan pangan dan juga makanan yang kurang seimbang.

Kurang gizi buruk pada balita merupakan fenomena gunung es yang dapatdigambarkan dengan keadaan gizi yang ada di masyarakat dan keadaankesejahteraan masyarakat seperti daya beli, pendidikan dan perilaku, lingkunganserta pemeliharaan kesehatan. Pencegahan dan penanggulangan masalah gizi tidakdapat dilakukan oleh satu sektor saja, tetapi memerlukan keterlibatan dariberbagai sektor dengan melakukan koordinasi dari antarsektor termasuk denganmasyarakat melalui prinsip kemitraan dan kebersamaan (Adisasmito, 2008).

Jumlah balita gizi buruk pada tahun 2009sebesar 14.735 balita atau 0,68\% dari jumlah balita yang ditimbang di posyandu dan semuanya telah dilakukan perawatan oleh petugas kesehatan (DinasKesehatan Provinsi NTB 2009).Jumlah kecamatan yang ada di Nusa Tenggara Barat yang rawan gizi sebanyak 136kecamatan atau 20,54\% dari 662 kecamatan yang ada di Provinsi Nusa Tenggara Barat Jumlah kecamatan yang bebas rawan gizi sebanyak 426 kecamatan (79,46\%), yang mendekati target cakupan yang diharapkan sebesar 80\%. Tiga kecamatantertinggi rawan gizi yang ada di Nusa Tenggara Barat yaitu 12 kecamatan rawan gizi diKabupaten lombok timur, 11 kecamatan di Kabupaten Sumbawa dan 10 kecamatan di Bima (Dinas Kesehatan Provinsi Nusa Tenggara Barat, 2010).

Hasil studi pendahuluan yang dilakukan peneliti pada bulan JuniTahun 2017 di Puskesmas Tentedengan wawancara terstruktur pada tenagakesehatan bagian gizi didapatkan bahwa Kecamatan Woha pada tahun 2016 memiliki balita BGM terbanyak dari seluruh kecamatan lainnya yang ada di Bima Nusa Tengara Barat sebesar 252 balita BGM dengan prosentase mencapai 6,40\%. Jumlah balitaBGM terbanyak selanjutnya yang ada di Dusun Anggrek0.68\%, Dusun Bantek 0.66\%, Dusun Kenanga 0.61\% dan Dusun Suka Maju 0.77\% (Puskesmas Tente, 2017).

Bayi dan balita yang Menderita Kalori Potein (KKP) tingkat dini akan mengakibatkan berat badannya tidak akan mempertambah dalam jangka waktu tertentu dan bahkan berat badannya menurun. Dampak lain dari KKP ini yaitu anak menjadi malas, kurang semangat dalam bermain, suka menyendiri, terserang penyakit dan penyakit yang di derita akan semakin parah, pertumbuhan tubuh tidak sempurna, perkembangan fisik dan mental menjadi terhambat yang menyebabkan Intelligence Quotients (IQ) menjadi rendah, produktifitas belajar kurang serta jika keadaannya semakin parah maka dapat menyebabkan kematian (Lia \& Mardiah, 2006).

Posyandu merupakan salah satu Upaya Kesehatan Bersumber DayaMasyarakat (UKBM) yang paling dikenal oleh masyarakat. Kegiatan yang ada diPosyandu terdapat lima kegiatan yaitu Keluarga Berencana (KB), Kesehatan Ibu dan Anak (KIA), gizi, imunisasi dan penanggulangan diare dapat digunakan 
sebagai upaya untuk menurunkan angka kematian bayi dan balita. Posyandumerupakan tempat pelayanan kesehatan masyarakat yang dapat mencapai masyarakat dengan perekonomian yang rendah. Posyandu sebaiknya dilakukan secara rutin kembali seperti pada masa orde baru karena posyandu dapat mendeteksi permasalahan gizi dan kesehatan di berbagai daerah Indonesia.Permasalahan gizi buruk pada anak balita, kekurangan gizi, busung lapar, dan masalah kesehatan lainnya termasuk kesehatan ibu dan anak dapat dicegah apabila posyandu dapat diaktifkan kembali melalui lima program kegiatan di posyandusecara menyeluruh di berbagai daerah Indonesia (Adisasmito, 2008).

Upaya pengembangan kualitas sumberdaya manusia dapat dilakukan secara merata dengan mengoptimalkan potensi tumbuh kembang anak mulai sejak dini. Posyandu merupakan sistem pelayanan kesehatan yang berbasis masyarakat yangdilakukan secara efektif dan efisien serta dapat menjangkau semua sasaran didaerah seluruh Indonesia yang membutuhkan layanan kesehatan anak, ibu hamil, ibu menyusui dan ibu nifas serta pasangan usia subur (Kementerian Kesehatan RI,2011).

Penimbangan balita yang dilakukan secara rutin di posyandu dan denganadanya penyuluhan serta pemberian makanan tambahan setiap bulan pada balita selama 3 bulan di posyandu, maka status gizi anak pada KMS dapat selaluterpantau oleh petugas kesehatan sehingga dapat menurunkan angka kejadiankasus gizi buruk atau pun gizi kurang (Djukarni, 2001 dan Puslitbang Gizi Bogor, 2007 dalam Octaviani, et al, 2008). Menurut survei data awal yang di dapat oleh peneliti, ibu yang kurang aktif dalam mengikuti kegiatan posyandu ada $9 \%$ di Desa Tente.

Berdasarkan latar belakang tersebut, maka penelitin ingin mengetahui bagaimana hubungan keaktifan ibu dalam posyandudengan penurunan jumlah balita BGM di Desa Tente Kecematan Woha.

\section{Metode Penelitian}

Jenis penelitian yang digunakan adalah penelitian survey analitik dengan menggunakan pendekatan cross sectional. Metode penelitian survey analitik adalah suatu penelitian yang mencoba menggali bagaimana dan mengapa fenomena itu terjadi. Cross sectional adalah suatu penelitian untuk mempelajari dinamika korelasi antara faktor-faktor resiko dengan efek, dengan cara pendekatan, observasi atau pengumpulan data sekaligus pada suatu saat (Notoatmodjo, 2010). Faktor resiko dalam penelitian ini adalah keaktifan ibu dalam posyandu dan ketidak aktifan ibu dalam posyandu, sedangkan factor efek adalah penurunan jumlah balita BGM. 


\section{Hasil Penelitian dan Pembahasan}

Pelaksanaan penelitian didahului oleh memperkenalkan diri peneliti dan memberikan informasi tentang maksud dan tujuan penelitian serta memberikan informasi mengenai balita BGM, selanjutnya peneliti memberikan lembar informed consent kepada responden. Peneliti menjelaskan tentang lembar informed consent tersebut. Responden yang bersedia menjadi subjek penelitian menandatangani lembar informed consent yang telah diberikan, dan apabila terdapat responden yang tidak bersedia menandatangani, maka peneliti tidak menjadikan responden tersebut menjadi subjek penelitian. Peneliti selanjutnya melihat KMS balita dari ibu yang datang ke posyandu untuk melihat status gizi balita dan keaktifan kunjungan ibu dalam posyandu. Jumlah kunjungan ibu ke posyandu selama 1 tahun terakhir pada KMS balita dimasukkan ke dalam lembar observasi keaktifan ibu ke posyandu untuk menentukan ibu yang aktif dan ibu yang tidak aktif ke posyandu sesuai dengan indikatorditentukan sebelumnya oleh peneliti.

Hasil coding yang sudah diolah dilanjutkan dengan pengkategorian yang didapatkan dari hasil karakteristik responden dengan anak yang balita BGM dengan balita tidak BGM, selain itu didapatkan juga data ibu yang aktif dan tidak ke posyandu. Proses entry dengan memasukkan data pengkategorian hasil pengkategorian yaitu SPSS. Cleaning dilakukan dengan pembersihan data-data yang tidak sesuai dengan kebutuhan dan pengecekan ulang terhadap data yang sudah di entry terdapat kesalahan atau tidak.

Uji statistik yang digunakan dalam penelitian ini adalah uji chi-square. Tujuan dari digunakannya uji chi-square adalah untuk menguji hubungan antara dua variabel kategorik. Penelitian ini menggunakan uji tersebut, untuk menguji hubungan keaktifan ibu dengan penurunan jumlah balita BGM di Desa Tente Kecamatan Woha Kabupaten Bima. Taraf signifikan yang digunakan dalam penelitian ini adalah 0,05 dengan keputusan Ho gagal ditolak bila nilai $\mathrm{p}>\mathrm{a}$, yang artinya tidak ada hubungan keaktifan ibu dengan penurunan jumlah balita BGM di Desa Tente Kecamatan Woha Kabupaten Bima, sedangkan untuk keputusan Ho ditolak bila nilai $\mathrm{p}<\mathrm{a}$, yang artinya ada hubungan keaktifan ibu dengan penurunan jumlah balita BGM di Desa Tente Kecamatan Woha Kabupaten Bima.

\section{a. Analisa univariat}

Tabel 5.1Distribusi Responden berdasarkan kunjungan ibu ke posyandu

\begin{tabular}{llll}
\hline No & Kunjungan ibu ke posyandu & Frekuensi & Prosentase \\
\hline 1 & Aktif & 146 & 76.8 \\
2 & Tidak aktif & 44 & 23.2 \\
\hline & Total & 190 & 100
\end{tabular}

Sumber: Data primer (2017) 
Tabel 5.1 menunjukkan bahwa jumlah responden yang aktif ke posyandu dan tidak aktif ke posyandu adalah tidak sama besar yaitu ibu yang aktif ke posyandu sebanyak 146 responden dengan prosentase $76,8 \%$, dan yang tidak aktif ke posyandu sebanyak 44 responden dengan prosentase $23,2 \%$.

Tabel 5.2Distribusi Responden di Desa Tente Kecamatan Woha Kabupaten BimaMenurut Balita BGM Sep $2017(n=190)$

\begin{tabular}{llcc}
\hline No & Balita BGM & Frekuensi & Prosentase \\
\hline 1 & BGM & 140 & 73.7 \\
2 & Tidak BGM & 50 & 26.3 \\
\hline & Total & 190 & 100 \\
\hline
\end{tabular}

Sumber: Data primer (2017)

Tabel 5.2 menunjukkan bahwa jumlah Balita yang tidak BGM sebanyak 50 responden dengan prosentase 26,3\%, dan yang BGM sebanyak 140 responden dengan prosentase $73.7 \%$.

b. Bivariat

Tabel 5.3 Hubungan Kunjungan Ibu Ke Posyandu Dengan Jumlah Balita BGM

\begin{tabular}{|c|c|c|c|c|c|c|c|}
\hline \multirow{3}{*}{$\begin{array}{l}\text { Kunjungan ibu } \\
\text { Posyandu }\end{array}$} & \multicolumn{7}{|c|}{ BGM } \\
\hline & \multicolumn{2}{|c|}{ BGM } & \multicolumn{2}{|c|}{ Tidak BGM } & \multicolumn{2}{|c|}{ Jumlah } & \\
\hline & $\mathrm{n}$ & $\%$ & $\mathrm{n}$ & $\%$ & $\mathrm{n}$ & $\%$ & \\
\hline Tidak Aktif & 4 & 2,1 & 40 & 21 & 44 & 23,2 & \\
\hline Aktif & 136 & 71,5 & 10 & 5 & 146 & 76.8 & \\
\hline Jumlah & 140 & 73,6 & 50 & 26,3 & 190 & 100 & \\
\hline
\end{tabular}

Sumber: Data primer (2017)

Berdasarkan tabel 5.3 diketahui bahwa dari 44 ibu $(23,2 \%)$ yang tidak aktif berkunjung ke posyandu, 4 ibu (2,1\%) yang mengalami balita BGM, 40 ibu (21\%) yang tidak mengalami BGM. 146 ibu (76.8\%) yang aktif berkunjung ke posyandu diketahui $136 \mathrm{ibu}(71,5 \%)$ yang mengalami balita BGM, $10 \mathrm{ibu}(5 \%)$ yang tidak mengalami balita BGM.

Berdasarkan analisis data penelitian yang menggunakan uji chisquare, didapatkan bahwa p value $=0,00$ dengan taraf signifikan (a) sebesar 0,05 . 
Berdasarkan hasil di atas, nilai $\mathrm{p}$ value lebih kecil dari nilai taraf signifikan $(\mathrm{p}<\mathrm{a})$, sehingga Ho ditolak yang artinya ada hubungan kunjungan ibu ke posyandu dengan jumlah balita BGM di Desa Tente Kecamatan Woha Kabupaten Bima.

\section{Pembahasan}

\section{Kunjungan Ibu ke Posyandu}

Berdasarkan Tabel 5.1 menunjukkan bahwa jumlah responden yang aktif ke posyandu dan tidak aktif ke posyandu adalah tidak sama besar yaitu ibu yang aktif ke posyandu sebanyak 146 responden dengan prosentase 76,8 $\%$, dan yang tidak aktif ke posyandu sebanyak 44 responden dengan prosentase $23,2 \%$.

Hasil penelitian ini sejalan dengan teori yang dikemukan oleh Sulistyoningsih (2011) mengatakan bahwa perilaku kesehatan terhadap sistem pelayanan kesehatan merupakan perilaku seseorang menyangkut respons terhadap fasilitas pelayanan, cara pelayanan, petugas kesehatan, dan obatobatannya yang terwujud dalam pengetahuan, persepsi, sikap dan penggunaan fasilitas, petugas, dan obat-obatan. Kesadaran ini sesuai dengan teori perilaku kesehatan yang meliputi pengetahuan (knowledge), sikap (attitude), dan tindakan atau praktik (practice) (Notoatmodjo, 2005). mulai muncul.

Peneliti menganalisa bahwa ibu yang aktif berkunjung ke posyandu untuk mendeteksi perkembangan balita akan memberikan pengaruh terhadap kejadian kejadian BGM pada balita, hal ini ditunjukan dengan hasil penelitian bahwa sebagian besar dari responden dengan frekuensi tertinggi adalah ibu yang aktif ke posyandu sebanyak 146 responden. Hal ini bahwa kunjungan ibu ke posyandu untuk mengetahui perkembangan balita akan memberikan kemungkikan untuk tidak terjadinya BGM pada balita. Hasil penelitian ini didapatkan bahwa ibu yang aktif ke posyandu dapat mencegah terjadinya peningkatan jumlah balita BGM melalui upaya mendeteksi secara dini status gizi balita setiap bulannya oleh petugas kesehatan bersama kader posyandu dalam memantau status gizi anak melalui buku KMS balita. Keaktifan kunjungan ibu ke posyandu dipengaruhi oleh beberapa faktor yaitu usia ibu, status maternal atau jumlah anak, pendidikan, suku atau kebiasaan, pengetahuan, pendapatan keluarga, pekerjaan ibu, dukungan tenaga kesehatan, kader posyandu dan dukungan tokoh masyarakat. Ketidakaktifan ibu ke posyandu didefinisikan sebagai perilaku dan sikap pengabaian terhadap posyandu. Ibu pada umumnya beralasan tidak mengetahui informasi mengenai posyandu, ibu lebih memprioritaskan pekerjaannya daripada berkunjung ke posyandu, posyandu terletak sangat jauh dari tempat tinggal ibu, dan tradisi pemberian obat tradisional turun temurun.

Ibu yang tidak aktif berkunjung ke posyandu mengakibatkan ibu kurang mendapatkan informasi mengenai pentingnya status gizi balita, tidak 
mendapat dukungan dan dorongan dari petugas kesehatan apabila ibu mempunyai permasalahan kesehatan pada balitanya, serta pemantauan pertumbuhan dan perkembangan balita yang tidak dapat terpantau secara optimal, karena pemantauan pertumbuhan balita dapat dipantau melalui KMS.

\section{BGM}

Berdasarkan tabel 5.2 menunjukkan bahwa jumlah Balita yang tidak BGM sebanyak 50 responden dengan prosentase 26,3\%, dan yang BGM sebanyak 140 responden dengan prosentase 73.7\%.

Hasil penelitian ini sejalan dengan teori yang dikemukan oleh Sediaoetama(2006) mengatakan bahwa Anak balita merupakan kelompok umur yang menunjukkan pertumbuhanyang pesat, sehingga memerlukan zat-zat gizi tinggi setiap kilogram beratbadannya. Anak balita ini justru merupakan kelompok umur yang paling sering menderita kekurangan gizi. Beberapa kondisi yang menyebabkan balita rawan giziyaitu anak balita masih dalam periode transisi dari makan bayi ke makanan orangdewasa, anak balita dianggap kelompok umur yang paling belum berguna bagikeluarga, ibu sudah mempunyai anak kecil lagi atau ibu sudah bekerja penuh, dananak balita masih belum dapat mengurus diri sendiri dengan baik, serta anakbalita mulai turun ke tanah sehingga terpapar dengan kondisi yang memungkinkanuntuk terinfeksi berbagai macam penyakit.

Peneliti menganalisa bahwa asupan gizi pada balita ditentukan juga oleh keaktifan ibu yang berkunjung ke posyandu, dikarenakan pada pelaksanaan posyandu ibu balita akan diberikan informasi tentang mengurus dan merawat balita. Sasaranposyandu adalah seluruh masyarakat utamanya yaitu: bayi, anak balita, ibu hamil, ibu nifas dan ibu menyusui serta Pasangan Usia Subur (PUS). Pelayanan posyandu pada hari buka dilaksanakandengan menggunakan 5 (lima) tahapan layanan yang biasa disebut sistem 5 (lima)meja. Kelompok sasaran yang selama ini dilayani dalam kegiatan yang ada diposyandu, yaitu 3 (tiga) kelompok rawan yaitu di bawah dua tahun (baduta), dibawah lima tahun (balita), ibu hamil dan ibu menyusui, denganmempertimbangkan terhadap urgensi adanya gangguan gizi yang cukup bermaknayang umumnya terjadi pada anak baduta yang bila tidak diatasi dapatmenimbulkan gangguan yang tetap, maka diberikan perhatian yang khusus bagianak baduta agar dapat tercakup dalam pemantauan pertumbuhan di posyandu.

\section{Hubungan kunjungan ibu ke posyandu dengan jumlah balita BGM}

Berdasarkan analisis data penelitian yang menggunakan uji chi-square, didapatkan bahwa $\mathrm{p}$ value $=0,00$ dengan taraf signifikan (a) sebesar 0,05. Berdasarkan hasil di atas, nilai $\mathrm{p}$ value lebih kecil dari nilai taraf signifikan $(p<a)$, sehingga Ho ditolak yang artinya ada hubungan kunjungan ibu ke 
posyandu dengan jumlah balita BGM di Desa Tente Kecamatan Woha Kabupaten Bima.

Hasil penelitian ini sejalan dengan teori yang dikemukan oleh Supariasa(2012) mengatakan bahwa balita BGM merupakan gambaran status gizi balita yang mengalami KEP sedang atau berat. Faktor yang dapat menyebabkan BGM yaitu penyebab langsung, penyebab tidak langsung, akar masalah, dan pokok masalah.

Menurut Sembiring (2004) mengatakan bahwa tujuan penyelenggaraan posyandu yaitu:

1) Menurunkan Angka Kematian Bayi (AKB), dan angka kematian ibu (ibu hamil, melahirkan dan nifas);

2) Membudayakan Norma Keluarga Kecil Bahagia dan Sejahtera (NKKBS);

3) Meningkatkan peran serta dan kemampuan masyarakat untuk mengembangkan kegiatankesehatan danKB serta kegiatan lainnya yang menunjang untuk tercapainya masyarakat sehat dan sejahtera;

4) Berfungsi sebagai Wahana Gerakan Reproduksi Keluarga Sejahtera, Gerakan Ketahanan Keluarga dan Gerakan Ekonomi Keluarga Sejahtera.

Peneliti menganalisa bahwa semakin aktifnya ibu yang berkunjung ke posyandu akan memberikan harapan dan kemungkinan untuk tidak terjadinya BGM pada balita, dikarenakan pada kegiatan posyandu segala informasi akan didapatkan oleh ibu balita terkait perawatan dan perkembangan balita.

\section{Keterbatasan Penelitian}

Penelitian ini memiliki beberapa keterbatasan dalam pelaksanaannya yang mengakibatkan penelitian tidak berjalan sesuai yang ditetapkan dan diharapkan oleh peneliti. Keterbatasan penelitian antara lain:peneliti memiliki kendala dalam melakukan penelitian dengan responden. Hal ini di sebabkan oleh seluruh responden tidak menggunakan KMS setiap mengikuti kegiatan posyandu untuk memantau berat badan setiap bulan anaknya dan status gizi anak dapat mengikuti garis pertumbuhan dan perkembangan yang normal dari KMS balita.Untuk menyamakan persepsi peneliti dengan responden dalam penelitian maka peneliti menggunakan bantuan mediator dari pihak kader posyandu.

\section{Kesimpulan}

Berdasarkan analisis data penelitian yang menggunakan uji chi-square, didapatkan bahwa p value $=0,00$ dengan taraf signifikan (a) sebesar 0,05 . Berdasarkan hasil di atas, nilai $\mathrm{p}$ value lebih kecil dari nilai taraf signifikan $(\mathrm{p}<\mathrm{a})$, sehingga Ho ditolak yang artinya ada hubungan kunjungan ibu ke posyandu dengan jumlah balita BGM di Desa Tente Kecamatan Woha Kabupaten Bima. Saran berdasarkan kesimpulan Ibu lebih aktif berkunjung ke posyandu di Desa Tente dalam memantau status gizi balitanya, apabila terdapat kendala dalam hal konsumsi makanan bagi 
balitanya, maka ibu dapat berkonsultasi dengan tenaga kesehatan dalam pemenuhan zat gizi balitanya. Saran Bagi Tenaga Kesehatan adalah Meningkatkan kualitas program posyandu agar ibu lebih tertarik untuk datang selalu setiap bulannya ke posyandu, memantau dan mendeteksi secara dini status gizi balita setiap bulannya di posyandu melalui KMS balita.

\section{Daftar Pustaka}

Adiningsih, S. 2010. Waspada Giz̨i Balita Anda. Jakarta: PT Elex Media.

Agus, R. 2013. Kapital Selektan Kuesioner : Pengetahuan dan Sikap Dalam Penelitian Kesehatan . Jakarta : Salemba Medika

Alfiyah. 2010. Upaya Menyikapi dan Mencegah Pernikahan Dini. Aryani, R. 2010. Kesebatan Remaja : Problem dan Solusinya. Jakarta : Salemba Medika

BKKBN. 2008. Kajian Pernikahan DiniPada Beberapa Provinsi Di Indonesia, Dampak Overpopulation, Akar Masalah dan Peran Kelembagaan Di Daerah.

BKKBN . 2010. Buku PendewasaanUsia Perkawinan Dan Hak-Hak Reproduksi Bagi Remaja Indonesia. Jakarta: BKKBNDirektorat Remaja dan Perlindungan Hak Hak Reproduksi.

Badan Pusat Statistik kabupaten bima. 2016. LaporanBulanan Data Sosial Ekonomi.

Darnita. 2013. Gambaran Faktor-Faktor Penyebab Pernikahan Usia Dini Di Kemukiman Lbok Kaju Kecamatan Indra Jaya Kabupaten Pidie Tabun 2013.

Dian, Luthfiyati. 2008. Metodologi Penelitian Kesehatan. Cetakan III. Jakarta : Rineka Cipta.

Eka, Yuli Handayani. 2013. Jurnal Maternity and Neonatal Volume 1 No 5 tentang FaktorFaketor Yang Berbubungan Dengan Pernikahan Usia Dini Pada Remaja Putri Di Kecamatan Tambusai Utara Kabupaten Rokan Hulu.

Hadi. 2008. Pendidikan suatu pengantar. Surakarta: Uns press

Hidayat, A. Aziz Alimul. 2012. Riset Keperwatan dan Tehnik Penulisan Ilmiah.Edisi Kedua. Jakarta: Salemba Medika.

Irwan, Djamal Zoer'aini. 2010. Prinsip-Prinsip Ekologi. Jakarta: Bumi Aksar. 
Kamal, Mustofa . 2012. Decline in Child Marriage and Changes in Its Effect on Reproductive Outcomes in Bangladesh, vol. 30. No. 3 hal 317-330.

\section{Internet Resources}

http://fenomenaremaja.com (diakses 27 Agustus 2017)

http://alfiyah23.student.Umm.Ac.Id/ (dikutip tanggal 29 Agustus 2017)

http://www.bkkbn.go.id (diakses 29 Agustus 2017)

http://bkkbn.go.id.depkes (diakses 29 Agustus 2017)

https://bimakab.bps.go.id/linkTabelStatis/view/id/144

http://www.ncbi.nlm.nih.gov/pubmed/23082634 (diakses tanggal 29 Agustus 2017) 